Econ Lit - 310

\title{
SPECIFICS OF THE NEW NORMATIVE DECISIONS REGARDING CONTRACTS FOR PROFESSIONAL QUALIFICATION
}

\author{
Assoc. Prof. Dr Andriyana Andreeva
}

\section{Introduction}

The labour market in Bulgaria in the years after the country's accession to the European Union has been very dynamic. This trend, combined with the rapid technological development of the society and the radical changes in global production, requires an adequate response in Bulgarian legislature. This is one of the main reasons for the normative changes in Bulgarian labour legislation which has been increasingly involving a process of "contracting". The amendments to Chapter XI "Vocational training" of the Labour Code (LC) from March 2014 attempted to update the labour and employment matters in the field of vocational training. The amendments to the regulations reflect the importance of the issues related to the vocational training of workers and employees. This is part of a trend imposed within the European Union and necessitates taking urgent measures at different levels in order to make Bulgarian workers and employees competitive both in the national and the international /specifically the European/ labour markets. This process of further vocational training is based on the Lisbon Strategy of 2000 for creating "a society based on knowledge" and for "lifelong learning".

The importance of vocational qualification has been evaluated by the Bulgarian legislators with the adoption of the CT of 1986 and this is reflected in the establishment of rules in a separate chapter "Vocational training". In this version of the law some mandatory provisions introduced bilateral obligations for the parties to an employment relationship aimed to maintain the vocational qualifications according to the requirements to the job and the needs of the enterprise (Article 127, item 9, Art. 132, item 6 of CT, revision 1986). (Mrachkov, C., 2010).

These norms were hastily repealed at the beginning of the transition period (repealed SG 100/1992) as a manifestation of the expansion of the parties' freedom of contract. Therefore, in the period until the accession of Bulgaria to the European Union the Bulgarian legislation in the part concerning vocational qualification fell in a kind of vacuum inconsistent with the European processes and trends. Provisions were approved in the LC - Art. 228a, Art. 228b - immediately after Bulgaria's accession to the European Union to restore the obligations of the parties under employment relationships with regard to the level of vocational qualification. It is an employer's obligation to provide conditions for keeping and improving the vocational qualification of workers and employees and a counter obligation of workers and employees to maintain their vocational qualification in accordance with the nature of the job. 
The evolution in the regulations related to the vocational qualification is also related to the evident process of "contracting" of labour law. The adaptability of the legal institution of contract, its adjustability to different legal environments and its ability to regulate various public relations on the basis of "the free will" of the parties is the reason to be used by the legislators in various fields.

The subject of this study is the contracts depending on the specifics in their subject matter, that is: an employment contract with a condition for training at work (Articles 230-233 of the LC), an employment contract with a condition for apprenticeship (Art. 233b-233c of the LC).

Therefore, the objectives of this study are:

1. To systemize the new types of employment contracts (EC) related to the vocational training of workers and employees.

2. To support their implementation with the legal analysis by linking their regulation to the general regulations of the institution of employment contract in Chapter V "Occurrence and change of an employment relationship", Section I "Employment contract" of the Labour Code.

\section{Evolution of contracts in labour law}

The evolutionary development of contracts in labour law is determined by the current social processes and their respective social relationships. The development of the institution of labour contracts in Bulgaria has its historical periods marked by the corresponding economic and historical stages of the country's development. Apart from the influence of internal factors these processes are also shaped by the relevant global (specifically European) processes.

The periods in the development of labour contracts may be described as follows:

a) Capitalist period - after Bulgaria's liberation in 1878 until 1944. At the beginning of the period there was no special legal framework for that legal institution and it was regulated by Art. 386-402 of the Obligations and Contracts Act (OCA) of 1892. The so-called "contract for hiring persons to work for the benefit of another one" (Art. 386, item 1 of the OCA) paved the way for the future development of employment contracts. Later on, an Ordinance-Law on Employment Contracts was adopted in 1936 setting the legal definition, conclusion, effect, rights and duties of the parties and respectively the termination of an employment contract. An Ordinance-Law on Collective Employment Contracts and Labour Conflicts was adopted in the same year. These are the main sources of employment contracts during that period (Oshanov, 1936; Stalev, Zh., L. Radoilski, 1948).

b) Socialist period - after 1944 until 1989. The period is influenced by the new social relations, both political and economic, entering Bulgaria. The capitalist foundations of the economy built so far in the country were demolished, approved international principles were replaced with new ones. An internal source on employment contracts for that period is the Labour 
Code of $1951^{1}$. The regulatory framework both of individual and collective employment contracts is minimalistic and consists in determination of the place and nature of the work (Art. 15 of the LC of 1951, repealed) in the former, and its consideration as a means for achievement and overachievement of a plan (Art. 9-14 of the LC of 1951, repealed). The Labour Code of 1951 (in its initial version) regulated in a similar way the place and role of an employment contract.

c) Modern stage of democratic development of Bulgaria under the condition of a market economy. The trend in the development of labour law in this period, especially in the recent decades, has a clear focus on contracts. It is no coincidence that legal experts talk about a process of "contracting" of labour law. More specifically, this process is also manifested in the growing diversity of the types of employment contracts, respectively the employment relationships they generate. The legislative changes in Bulgarian labour law in this respect are not isolated but represent a process determined by the socio-economic needs of the labour market in the country and continuing the European process within the EU.

These conditional stages in the development of the institution of employment contract show not only the evolution in its development, but also reveal the need for better understanding of the different types of employment contracts in order to use them correctly in practice.

The legal framework regulating the types of employment contracts has not been completely systematized in the LC but is dispersed in different places within the Code: Chapter V - "Occurrence of an employment relationship", section I - "Employment contract", section IX "Additional labour under an employment contract". These contain the main part of the diverse types of employment contracts, however, provisions are included also in other parts of the LC dedicated to different employment institutions, e.g. Chapter XI "Vocational qualification", Chapter XII "Salaries and wages", section III - "Additional and other types of remuneration". The legislative motivation to include individual types of employment contracts in various parts may be linked to the specifics of the matter to which the respective employment contract is made to correspond. This fragmentation in the legal matter of the legal institution of employment contracts and the various aspects of their diverse types makes it difficult to find the relevant matter and its proper interpretation through specific legal techniques. Being systematically referred by the legislature to legal institutions different from the employment contract, the specific individual types of contracts are difficult to be integrated both as a doctrine and into the practice of classification of the types of employment contracts. This requires their detailed study and summary within the employment doctrine with a view to determining a common classification feature for systemization. Thus a system of the types of employment unified on the basis of the

\footnotetext{
${ }^{1}$ As a member of the ILO during that period Bulgaria ratified a number of conventions including in the field of employment contracts however the author has focused predominantly on the internal regulatory framework adopted by the Bulgarian legislature.
} 
single legal institution - employment contract - can be created reflecting, however, the specifics of the "content" the elements of which determine the different types.

\section{Specific features of the new types of employment contracts in the field of vocational qualification}

This classification group of employment contracts reflects the modernization of the Bulgarian legislation in the sphere of vocational qualification - that is an employment contract with a condition for training at work (Articles 230-233 of the LC) and an employment contract with a condition for apprenticeship. They aim to support workers and employees in their training and to enable employers to adapt and meet the challenges posed by a combination of factors such as globalization and the aging Bulgarian population.

With amendments in the provisions regulating the apprenticeship contract it is renamed to "employment contract with a condition for training at work" (title amended - SG 27/2014, previous title: apprenticeship contract). The regulation of that type of employment contract is laid down in the provisions of Article 230-233 of the LC.

The legal essence comes from the legal title, i.e. it is an employment contract subject to, besides the specific regulations (Article 230-233 of the LC), all norms of the general regulation of the institution of employment contract in terms of procedure and form of conclusion, rights and obligations of the parties, etc. This is explicitly provided in the provision of Art. 233 of the $\mathrm{LC}^{2}$. It ensues from the general provisions and the requirement of Art. 62, par. 1 of the LC that an employment contract with a condition for training is to be concluded in written form. A notification of the conclusion of such contract is filed with the relevant territorial department of the National Revenue Agency (TD of NRA) ${ }^{3}$. The specific features of that contract consist in the result it aims to achieve, i.e. the employer undertakes to train a worker or an employee in a particular profession or vocation in the course of work and the trainee is to learn such profession or vocation.

The legislator has regulated the maximum length of the period in explicit provisions (Art. 230, par. 2 of the LC) and the minimum salary (Art. 230, par. 4 of the LC) under such contract. The contract may have a fixed period of validity and the period of training may not exceed 6 months except in cases of training through work (dual training) organized under the terms and procedure of the Vocational Education and Training Act. It can be concluded from the analysis of that provision that generally the period of the contract is up to 6 months and such contract may be concluded only once with a particular worker or employee at a particular enterprise for training in a particular vocation. The legislator has introduced that fixed period due to a complex of reasons. Firstly, that is an optimal period in view of the knowledge to be acquired by a worker or employee related to their vocational training. Secondly, the period corresponds to

\footnotetext{
2 Art. 233. (Amended - SG 100/1992, amended SG 27/2014) The effective labour law applies to the relationships between the parties to the employment contract with a condition for training at work.

3 According to Ordinance 5/29.12.2002 on the content and procedure of sending a notification under Art. 62, par. 5 of the LC under Annex 1 to Art. 1, par.1 of that contract is registered with code 14.
} 
the remuneration during the period of training. The trainee receives remuneration corresponding to the performed work but not less than 90 percent of the minimum salary set for the country. Obviously, the aim of the legislator was to turn the period of the contract into a guarantee against malpractices by employers who tend to save on remuneration by signing a series of contracts for training.

With regard to the period of the contract the law has introduced an exception according to which the period may exceed the maximum threshold of 6 months in the cases of the so called dual training. In this hypothesis the provision of the LC is a blanket rule complemented by the Vocational Education and Training Act (VETA). According to Art. 5, par. 4 of that special act vocational training may take place also in the form of training through work (dual education). The training through work (dual training) is a form of partnership between a vocational school, a vocational college or a vocational training centre and one or several employers that includes:

- practical training in an actual working environment;

- training at a vocational school, a vocational college or a vocational training centre.

In the special act the legislator has provided also norms regarding the organization of the training through work (dual training) that correspond to the norms of the LC. According to the new provision of Art. 17a, par. 1 of the VETA that training is a specific form of vocational training for acquiring professional qualification that is organized on the basis of a partnership or a contract between the institutions under Art. 5, par. 4 of the VETA and one or several employers.

In the final stage of the effect of the contract, the outcome from the training under the contract under Art. 230, par. 1 is established through an examination of the trainee conducted under the terms and procedure determined by the employer. For training for acquisition of vocational qualification the examination takes place under the terms and conditions of the Vocational Education and Training Act. Where the trainee has successfully passed the examination they are issued a document demonstrating the acquired competence and skills. For training for acquisition of vocational qualification the results from the training are verified under the terms and conditions of the Vocational Education and Training Act.

The practical implementation of the provision gives rises to issues related to the quality of the training and the current general threshold of 6 months. To allow employers more flexibility the legislator should envisage exceptions from the upper threshold of the period of training taking into account the requirements and the characteristics of different vocations. (Bogomilova, Zh. Employment contract with a condition for training at work. Labour and Law, issue 10, 2014, page 14).

A new employment contract provided in the amendments made to the LC in March 2014 in Chapter XI "Vocational qualification" is the contract for apprenticeship.

Its legal provision is in Art. 233b-c of the LC. With the inclusion of that new type of employment contracts in the system of employment contracts in the LC their number reaches 19 which is additional confirmation of the intensifying process of "contracting" of Bulgarian labour law. With this new type the legislator aims to regulate a contract 
designed directly for young people graduating from secondary or higher educational institutions but without work experience ${ }^{4}$. The problems before the introduction of that type of employment contract consisted mainly in the employers' negative attitude and refusal to accept young people with education corresponding to a position but without work experience and length of service. That lack of competitiveness of the young people on the labour market is one of the reasons for the unfavourable trend of high youth unemployment in Bulgaria and the EU. The package of measures developed the European level is complemented by the EU recommendation to the Member States to extend the application of the apprenticeship contract in their domestic laws. As indicated by the systematic place of that contract in Chapter XI "Vocational qualification", immediately after the employment contract with a condition for training at work, the legislator has logically enriched and extended the employment contract types related to training and its upgrading. On the basis of the selected systematic place of the regulation of the two contracts it can be concluded that the legislator's intention was directly related to the improvement of the vocational qualification of workers and employees. This however does not justify the growing lack of regulatory systematization of the types of contracts. It is one of the reasons for the difficulties in the practical application of the otherwise rich diversity of employment contract types.

The legislator has set two restrictions on the conclusion of apprenticeship employment contracts. The first limits the age of the apprentice to 29. That maximum age limit is taken into account at the time of conclusion of the employment contract and the intention is to aim the apprenticeship at the young people having the relevant education but no work experience. The education of an apprentice is the second limitation for conclusion of that type of contract. The regulatory requirement of Art. $233 \mathrm{~b}$, par. 1 of the LC is that the education (secondary or higher) is to correspond to the work for which the apprenticeship contract is concluded. With these two requirements specific for the apprenticeship contracts the legislator intends to close the existing vacuum in the education-work relationship.

Within the meaning of Art. 233a of the LC apprenticeship is the key element of the apprenticeship contract. All other arrangements between the parties are the common elements in the content of every employment contract. For that reason the legislator has regulated the specific legal issues concerning the method and form of apprenticeship, the name and position of the mentor, the duration of the apprenticeship contract. The analysis of the legal regulation of the apprenticeship contract shows some specific features differentiating it in the first place from the contract for training at work and making it a form of "transition" from education (secondary or higher) to the beginning of employment in the acquired profession or vocation.

A specific feature of that type of contract is the work under mentorship. The legislator vests responsibilities in the person designated to act as mentor who is responsible in practice for the good acquisition of practical skills by the apprentice. The relationship between the employer and mentor is settled in an additional agreement to the mentor's employment contract. In that sense the mentor builds upon the theoretical

\footnotetext{
${ }^{4}$ See National Assembly, ref. 402-01-7 of 21.01.2014 - justification of the bill for amendment of the LC.
} 
knowledge of the apprenticeship with habits and skills typical of the relevant profession. It can be therefore concluded that the process of apprenticeship builds upon the knowledge acquired in the educational system. To guarantee the quality of the mentorship the legislator has put in place a requirement that the mentor has "at least three years' work or professional experience in that profession". Besides the positive objectives pursued by the newest type of employment contract there are also some legal errors. As already discussed it is regulated in an unsuitable place which, first of all, makes difficult its practical application as it is related to another legal institution and not to the basic legal institution of employment contracts. Second, the legislator has mixed in some places the apprenticeship with the "contract for training" in some provisions. This can be observed in the requirement of Art. 233c "within 14 days from the termination of the contract under Art. 233b the employer shall issue to the apprentice a recommendation verifying the outcomes from the training". That legal text needs to be further refined because of its internal contradiction. The requirement for issue of a letter of recommendation contradicts the idea of objectivity of the results achieved by the apprentice. It can be issued only in case the person has actually had positive results during the period of apprenticeship. In all other cases the accurate term is a certificate corresponding to the provision of Art. 128a, par. 2 of the LC regarding the documents issued by the employer.

\section{Conclusion}

Besides the positive aspects including the enrichment of the range of contract types in the modern employment law the current regulations of employment contracts related to vocational qualification contain a number of errors discussed above. The purpose of this is to draw the attention of the employment law experts to make an indepth analysis in that direction and to ensure a future legislative reaction through amendments to the regulation of those contracts.

\section{Literature}

1. Bogomilova, Zh. (2014) Trudov dogovor s uslovie za obuchenie po vreme na rabota. Trud i pravo, br. 10. p. 14.

2. Mrachkov, V. (2010) Dogovorat v trudovoto pravo.Sofiya: Sibi, p. 158.

3. Oshanov, R. (1936) Komentar na naredbata-zakon za trudoviya dogovor. Sofiya, p. 1-17.

4. Stalev, Zh., L. Radoilski. (1948) Trudovi zakoni. Test i sintez na yurisprudenciyata. 2 ed. Sofiya, p. 19-63. 


\title{
SPECIFICS OFTHENEW NORMATIVE DECISIONS REGARDING CONTRACTSFOR PROFESSIONALQUALIFICATION
}

\section{Assoc. Prof. Dr Andriyana Andreeva}

\begin{abstract}
In the article there are discussed the essential characteristics and specificity of the contracts of employment connected with the professional qualification of the workers and employees, being a new legislative decision introduced with the changes in the Labour Code in 2014. There is analyzed the current legal organization of these contracts and on that basis there are drawn conclusions and recommendations with respect to their practical application, as well as proposals de lege ferenda for improving the normative base.

Keywords contract of employment, apprenticeship, training, professional qualification.
\end{abstract}

